【論 文】

UDC : $628.86: 628.854$
日本建築学会計画系論文報告集 第 429 号・1991 年 11 月 Journal of Archit. Plann. Environ. Engng, AIJ, No.429, Nov., 1991

\title{
室内気流の流速と乱れの強さのサーマルマネキン各部の 対流熱伝達率への影響に関する研究 \\ AN EXPERIMENTAL STUDY ON CONVECTIVE HEAT TRANSFER COEFFICIENT DISTRIBUTION ON THERMAL MANIKIN BY AIR FLOW WITH VARIOUS VELOCITIES AND TURBULENCE INTENSITIES
}

\author{
李徹球*,メリコフ A.K. ${ }^{* *}$, 本間 宏*** \\ Chulgoo LEE, Arsen Krikor MELIKOV and Hiroshi HOMMA
}

\begin{abstract}
The impact of velocity and turbulence intensity of airflow on convective heat transfer coefficient distribution on a thermal manikin was experimentally investigated using a turbulence intensity changeable low airflow producer. When the velocity of forced airflow was below $0.2 \mathrm{~m} / \mathrm{s}$, the convective heat transfer coefficient changed little at the lowest part of the foot and increased at the upper part compared to the condition of natural convection. It increased over the whole surface when forced airflow was over $0.3 \mathrm{~m} / \mathrm{s}$. The heat transfer coefficient increased significantly with the turbulence intensity, when the forced convection was over $0.3 \mathrm{~m} / \mathrm{s}$.
\end{abstract}

Keywords : convective heat transfer coefficient, turbulence intensity, thermal manikin, low airflow producer, natural convection, forced convection

対流熱伝達率, 乱れの強さ, サーマルマネキン, 微風速発生装置, 自然対流, 強制対流

\section{1. 序}

室内で自然にまたは強制的に生ずる気流は室内の温熱 環境を構成する主因子の一つであり，居住空間の快適状 態に強い影響力を持つ。この気流が人体の対流熱放散に 及ぼす影響については，人体またはサーマルマネキン等 を対象にし，様々な実験が行われ，対流熱伝達率を流速 の関数として多くの実験結果が出されてきた。これらの 実験式の中には Colin らの式のように対流熱放散に よって生じる自然対流の影響を加味した式もある”。こ れらの研究は人体全体の熱バランスを確立するには有効 であるが, ドラフトと定義されている，人体の部分的冷 却を予測するには不十分である。

ドラフトに関する最初の包括的な研究として, Houghten らが 10 名の被験者を対象にして行った研究 がある ${ }^{2)}$ 。彼らは各被験者の首の後面と足首を独立に気 流にさらしでドラフト反応を調查したが，足首では気流 の温度が約 $19.5^{\circ} \mathrm{C}$, 流速が約 $0.25 \mathrm{~m} / \mathrm{s}$ の場合, 不快を 感じる被験者の比率は約 $10 \%$ であったが，首後面では
約 $40 \%$ であったことを報告した。McIntyre は Houghten らと類似な実験を行い; 被験者の頭部を気流に暴露 し, 温度 $23^{\circ} \mathrm{C}$ で流速 $0.25 \mathrm{~m} / \mathrm{s}$, また温度 $21^{\circ} \mathrm{C} て ゙$ 流速 $0.2 \mathrm{~m} / \mathrm{s}$ を持つ気流では誰も不快感を感じないと述へて いる3)。Berglund らは50名の被験者を対象に実験を行 い, 流速 $0.25 \mathrm{~m} / \mathrm{s}$ 以下なら室内の快適条件に影響を及 ぼさないと発表している4)。しかし，これらの研究で用 いられた気流は層流または層流に近い気流である。 ASHRAE STANDARD，ISO 等の快適基準に定まって いるドラフトについての基準は大部分，気流の平均速度 に根拠を置いている。様々な原因により室内に存在する 気流は一般的に乱流であり，その程度を表している乱れ の強さ (Turbulence Intensity 以下 T.I. と略記) は 10 〜70\%に至っていると言われている5)。

Fanger と Pedersen は非定常流に被験者をさらす実 験を通じて，変動気流（乱流）は層流よりもっと不快感 を与えることを示した6)。 Melikov は Fanger, Christensen と Berglund, Fobelets が各々行った類似な気流速
* 豊橋技術科学大学建設工学系 大学院生·工修

** デンマーク工科大学 研究員・工博

豊橋技術科学大学建設工学系 教授・工博
Graduate Student, Dept. of Regional Planning Technical Univ. of Toyohashi, . M. Eng.

Research Engineer, Laboratory of Heating and Air Conditioning Technical Univ. of Denmark, Dr. Eng.

Prof., Dept. of Regional Planning Technical Univ. of Toyohashi, Dr. Eng. 
度と気流温度の範囲で被験者の不快度を調べる研究を比 較し, 気流の温度が $21^{\circ} \mathrm{C}$, 平均気流速度が $0.3 \mathrm{~m} / \mathrm{s}$ の 場合, Berglund らの実験において不快を感じた被験者 の比率は約 $23 \%$ であるが，Fanger らの実験では $45 \%$ を超えており，これは主に乱れの強さの差が原因である と提起している7。両方の実験における乱れの強さは共 に平均流速が増加するに従って娍少したが，その範囲は Berglund らの実験においては5 40\%,Fanger らの実 験においては $30 \sim 65 \%$ であった。乱れの強さの，人体 のドラフト反応への影響を調べるために，Fanger らは 3 種類の乱れの強さ (T. I. $<12 \%, 20 \%<$ T. I. $<35 \%$, T.I. $>55 \%$ ）を持つ気流を用いて人体のドラフト反応 を測定し，同じ平均流速では乱れの強さが大きいほよ゙不 快感が大きくなると報告しだ゚。 Mayer は加熱頭部モデ ルを種々の流速と乱れの強さを持つ気流にさらして行っ た実験でモデルの対流熱伝達率は気流の平均流速と乱れ の強さを掛けた値の平方根に比例して増加すると言って いる9!。しかし，これらの研究における気流は強制対流 を対象にしており，人体または発熱モデル自身の発熱に よる自然対流の影響は考慮していない。人体自身の発熱 により人体周辺に生じる上昇気流は上半身では 0.25 $\mathrm{m} / \mathrm{s}$ 近くなっており，これは快適基準に定められている 気流の許容範囲の上限に匹敵する值である。また，この 上䍙気流は人体各部位ごとの自然対流熱伝達率に影響を 及ぼしている。居住空間に存在する室内気流はこの居住 者からの自然対流之競合し，この二つの気流の競合はド ラフトについての人体の反応をより複雑にすると思われ る。人体の各部位の対流熱伝達率は人体が発生する自然 対流が強制対流にどのくらい入り込まれるかによると考 えることも出来る。

このように，室内気流中の乱れの強さは人体のドラフ トへの反応に大きな影響力を持つことが示されてきた。 しかし，乱れの強さの物理的な側面，特に人体が発生す る自然対流と強制対流の共存下における乱れの強さの影 響についての知識が不足している。そこで本研究は乱れ の強さによる人体の各部位ごとのドラフトの物理的性状 を調べるために人間と同じ形状をしているアルミ鋳造外 殻を持つサーマルマネキンを用いて，マネキンの局部対 流熱伝達率への強制対流の乱れの強さの影響と, マネキ ンから発生する自然対流とその自然対流に入り込む強制 対流の相互作用について実測を行い，その結果を検討し た。強制対流の流速が遅い場合, 熱伝達に対して気流の 影響が最も強く現れるのは気流に正対する面である。本 実験では，自然対流と共存する強制対流の影響を明確に 把握するために，水平気流に正対する面における測定を 行った。

\section{2. 実験方法}

\section{1 実験対象および実験空間}

実験対象として図一1に示す身長 $1.705 \mathrm{~m}$ の男子体形 のサーマルマネキンを用いた。これはアルミで中空に作 られており, 頭, 胸, 腹, 両腕, 両脚部の 7 部分に分割 されている。この.7つの各部分の内部にはヒーターと ファンが組み込まれ, 電力供給の自動調節によって各部 の内部温度が均等になるようになっている。表面は人体 とほぼ同じ放射率を持つ黒色焼付塗装が施されている。

本実験は気密性, 断熱性が優れており, 外気温変動の 室内への影響の少ない奥行, 長さ, 天井高さそれぞれ 6. 65，16，3.15 m の部屋の中に，さらに実験のために 作り出す気流以外の, 室内で生じる気流を㵂断するため に，木材を骨組みにし内部をアルミ板で貼った $1.8 *$ $5.85 * 2.35 \mathrm{~m}$ の実験空間を作って行った。実験空間の 床は部屋の床からの熱伝導を防ぐために厚さ $0.1 \mathrm{~m} の$ 発砲スチロール板を敷いた。実験空間の中心は後述する 4 台の微風速発生装置とサーマルマネキンが入ってお り, 測定機器とそれをコントロールするコンピューター は実験空間の外に配置し，測定者は気流の性状を調節す る時のみ実験空間に入り,データの収集は室外で行った。

\section{2 実験装置および実験方法}

乱れの強さが変化する水平気流を作るために図一 2 に 示すように幅，高さ，長さそれぞれ $0.92 ， 0.465 ， 1.7$ $\mathrm{m}$ の装置を 4 個作り，それを 4 段に重礼ることによっ て $0.92 * 1.86 * 1.7 \mathrm{~m}$ の水平微風速発生装置になるよ うにした。実験対象になる立位マネキンは身長 $1.705 \mathrm{~m}$, 最大幅が $0.62 \mathrm{~m}$ であるので, 装置の縦と横はマネキン の頭上と両腕の外側より約 $0.15 \mathrm{~m}$ ずつ大きくした。ま

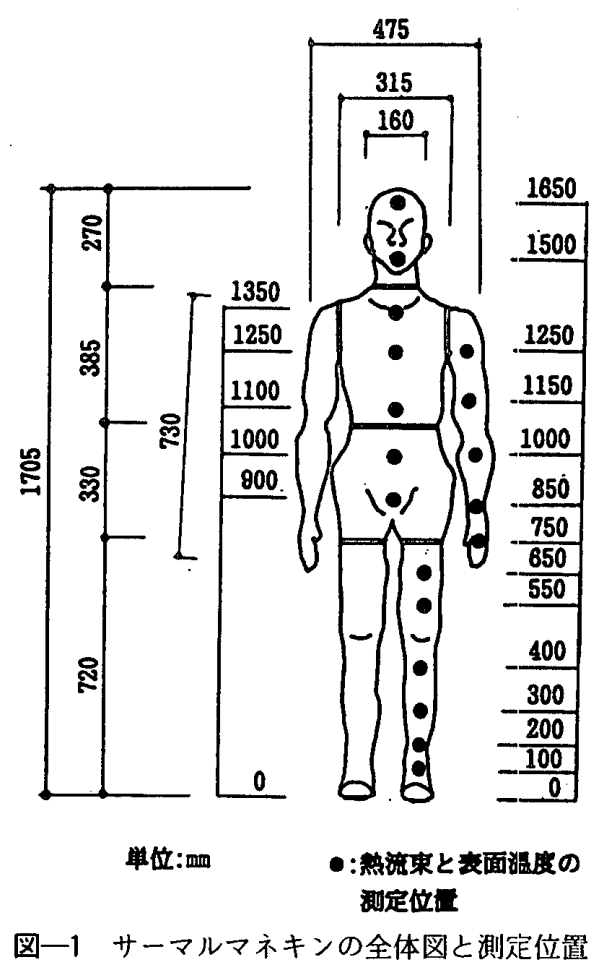




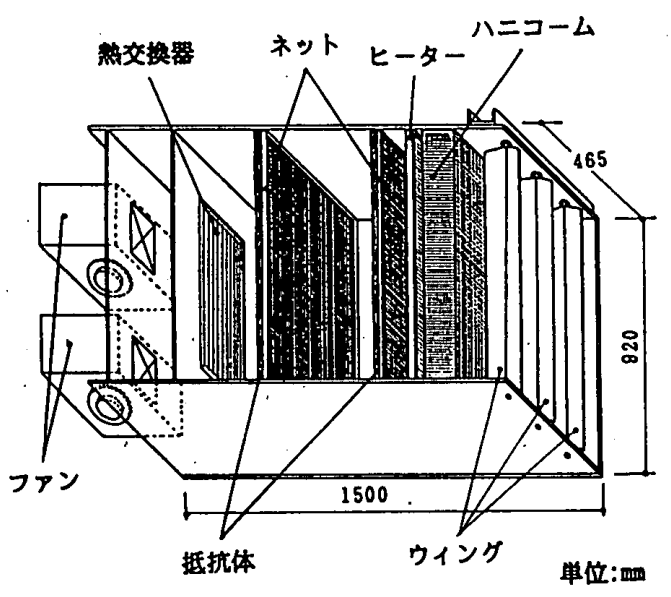

図一2 微風速発生装置の構造

た，装置の中に気流を制御するために必要な構成品を設 置するために装置の長さは $1.7 \mathrm{~m}$ とした。4 個の装置は 個々に調節でき，均等な気流を発生したり，4個の装置 から気流を独立に発生したりして色々な形のドラフトが 生じるようにした。本研究では 4 個の装置全部から同じ 気流を発生した場合について報告する。

各装置の外側は合板で造られており, 出力 $100 \mathrm{~W}$ 遠 心送風機 2 台が装置を通して気流を押出すようになって いる。吹出し口において流速を均等にさせるために各々 15 枚と 10 枚のフィルタを重ねた $2 つ$ 抵抗体を設置し た。フィルタはレンジの排気フードに用いられる不燃性 不織布を用いた。また, 気流の乱れを一度できるだけ小 さくするために整流器として厚さ $0.1 \mathrm{~m}$ のハニコーム を取り付けた。最終段階で乱れを与え，その強さを変化 させるため出口に 3 枚のウィングを軸を水平に取り付 け，気流を層流の状態から任意の乱れの強さを持つよう にコントロールした。3枚のウィングの回転はそれぞれ ステッピングモーターの円運動によって行われた。ス テッピングモーターの回転速度は実験に応じて設定され た範囲内で一定に，回転角度は笧囲内でランダムに動く ようにした。この角度は制御用コンピューターのランダ 么関数を利用している。3枚のウイングの寸法は各々 $0.13 * 0.87 \mathrm{~m}$ であり, 装置の吹出し口のほぼ全面積を カバーしている。さらに，装置からの気流の温度を調節 するためにクーラー用熱交換器とニクロム線を張った ヒーターを取り付けた。今回の実験では熱交換器とヒー ターは稼働しなかった。装置から出る流速は $0.1 \mathrm{~m} / \mathrm{s}$ 以 下から $1 \mathrm{~m} / \mathrm{s}$ 以上まで広く調節できる。乱れの強さは $5 \%$ から $50 \%$ の間で調節可能である。装置から発生す る気流のエネルギースペクトルはウェーブ数約 $10 \mathrm{~m}^{-1}$ までほぼフラットで，これ以上では急激に低下する。

予備実験として変動因子である気流の速度および乱れ の強さと遠心送風機の送風量および 3 枚のウィングの回 転速度と角度の関係を求めた。用いた流速計のプローブ は加熱棈円球型の風速計である。乱れの強さは次式に
よって算出した。

T. I. (Turbulence Intensity)

$=(\mathrm{S} . \mathrm{D} . / V) * 100(\%)$

ここで, $V$ は平均流速, S. D. は流速の標準偏差で風速 計により直接表示される。

この微風速発生装置では, 装置からの距離により気流 の流速と乱れの強さに関する特性が異なる。装置から近 い所では乱れが少ないのでウィングの操作により乱れの 強さの調節が自由にできるが, 遠い所では自然に乱れが 加わり, 乱れの強さの低い気流は得にくい。一方, 装置 から近い所では 4 段に重ねた各装置の間の継ぎ目で気流 の不連続性があるが, 遠い所ではこのような不均一性は なくなる。本実験の予備テストとして微風速発生装置か ら $0.2 \sim 1 \mathrm{~m} の 6$ か所で平均流速と標準偏差を測定した 結果, $0.8 \mathrm{~m}$ 以上離れた所では低い速度で低い乱れの強 さの気流（流速 $0.2 \mathrm{~m} / \mathrm{s}$ 以下で乱れの強さ $10 \%$ ）は得 られなかつた。一方, 装置から $0.2 \mathrm{~m}$ 以内の範囲では, 各装置間の継ぎ目における気流の不連続性のため流速之 乱れの強さの均一性の面での調節が困難であった。 0.3 $\sim 0.7 \mathrm{~m} / \mathrm{s}$ では気流の乱れの強さの調整も比較的容易に でき, 装置の各部分間の流速の差も $5 \%$ 以下であった のでマネキンの位置は上記範囲の中間である，装置から $0.5 \mathrm{~m}$ 離れた所に設定した。マネキンにさらした気流は 平均速度が $0.12,0.2,0.3,0.42 \mathrm{~m} / \mathrm{s}$ の 4 種類. 乱れ の強さは約 $10,30,45 \%$ の 3 種類とした。ただし, 流 速 $0.12 \mathrm{~m} / \mathrm{s}$ の場合の乱れの強さ $45 \%$ および流速 0.42 $\mathrm{m} / \mathrm{s}$ の場合の乱れの強さ $10 \%$ は気流が不安定なため,

実験できなかった。

マネキンの各部の表面温度の測定に使用した熱電対は

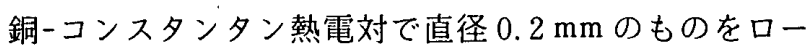
ルにより幅約 $0.8 \mathrm{~mm}$ ，厚さ約 $0.01 \mathrm{~mm}$ に伸展し測定表 面への接触面積を拡大するとともに表面の平滑化を図っ た。マネキン各部の表面熱流を測定するための熱流セン サーは公称感度 $465 \mathrm{~W} / \mathrm{m}^{2} \cdot \mathrm{mV}$ で寸法 $30 * 15 * 1.5 \mathrm{~mm}$ の軟質シリコンゴムで作られたものを使い，取り付けた センサーとマネキン表面の間にすき間が生じないように 心がけた。測定点の位置は図一1に示す。

\section{3 放射熱放散量の補正}

モデルと周辺との熱交換の内，放射による影響を把握 するために，モデル表面の放射率と類似な放射率を持つ と考えられる厚さ $6 \mathrm{~mm}$ の黒いゴムで包まれた直径 72 $\mathrm{mm}$, 長さ $840 \mathrm{~mm}$ の円筒を実験空間に設置して予備実 験を行った。実験の方法については参考文献 10）を参 照のこと。完全黒体の放射定数約 $5.67 \cdot \mathrm{W} / \mathrm{m}^{2} \mathrm{~K}^{4}$ に, 放 射熱交換が行われる2 面の放射率 $\varepsilon_{1}, \varepsilon_{2}$ をかけたことを 意味し， 2 面間の温度差とともに両面の放射熱交換量の 程度を決める因子である有効放射定数は，本実験の場合 $4.8 \mathrm{~W} / \mathrm{m}^{2} \mathrm{~K}^{4}$ であった。以下の計算ではこの有効放射定 
数値を用いて放射熱放散量を計算し，これを表面熱流か ら差し引いた残りを対流熱放射量とした。

\section{4 対流熱伝達率の算出}

マネキンの各部位の対流熱伝達率は各部位ごとの表面 温度と熱流束の測定値より求めた。マネキンの表面は全 体的に等温になるように部分ごとに発生熱量を調節し

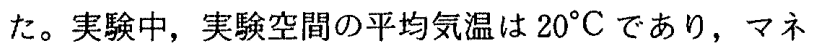
キンの表面温度と周辺気温との温度差は $7^{\circ} \mathrm{C}, 10^{\circ} \mathrm{C} の$ 2 段階を目標値として夷験を行った。各々の条件下での 測定を行う前に 10 分以上その状態の気流にマネキンを さらしてから測定を始め, 約 33 分にわたって 100 回表 面温度と熱流束を測定した。各測定点のデータの標準偏 差は強制対流の平均流速と乱れの強さによって変化した が，無風状態の場合，マネキン表面の平均温度 $29^{\circ} \mathrm{C} の$ 時, 標準偏差は約 $0.06^{\circ} \mathrm{C}$ であった。マネキン表面の各 部位別対流熱伝達率は熱電対で求めた表面温度と周辺空 気温度, 熱流センサーで求めた熱流束および前述の方法 で算出した放射熱量を用いて，ニュートンの冷却則より 算出した。算出過程については参考文献 10）を参照の こと。

\section{3. 実験結果}

図-3 -6 は室内気流の平均流速が各々 $0.12,0.2,0.3$, $0.42 \mathrm{~m} / \mathrm{s}$ の時の乱れの強さをパラメータとしたマネキ ンの各部位別対流熱伝達率を示す。マネキンの表面温度 と周辺空気温度との差は約 $10^{\circ} \mathrm{C}$ である。図一6中の実 線は微風速発生装置を停止した状態での各部位別対流熱 伝達率を示す。平均流速が $0.12 \mathrm{~m} / \mathrm{s}$ の図一3において 下端を除く脚部之腕部の対流熱伝達率は無風時に比べて

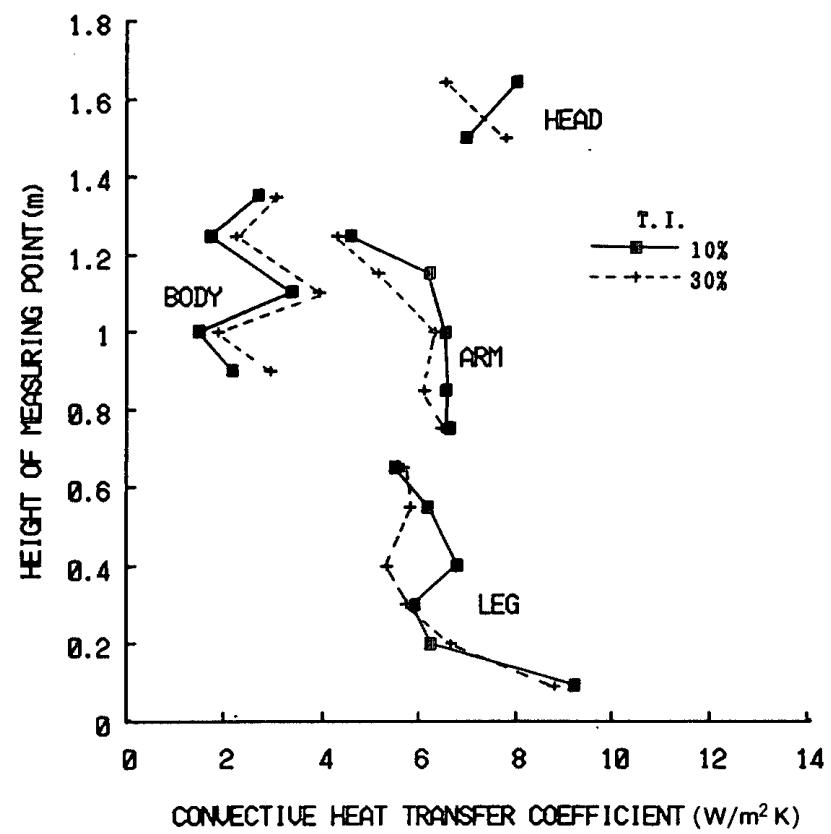

図一3 マネキン各部位別対流熱伝達率 (マネキンと周辺との温 度差: $10^{\circ} \mathrm{C}$, 平均気流速度 : $0.12 \mathrm{~m} / \mathrm{s}$ )
$2 \sim 3 \mathrm{~W} / \mathrm{m}^{2} \mathrm{~K}$ 程度大きかったが，部位による対流熱伝達 率の分布の形は無風時とほぼ近似しており，脚下端の值 が極端に大きい。頭部においては対流熱伝達率が無風時 に比べて約 $2 \mathrm{~W} / \mathrm{m}^{2} \mathrm{~K}$ 大きかったが, 乱れの強さが変 わっても部位による変化に規則性が見られない。胴部に おいては值も形も無風時と大きな差はない。全体的に強 制対流の乱れの強さによる対流熱伝達率の変化に規則性 は見られない。平均流速が $0.2 \mathrm{~m} / \mathrm{s}$ の図一 4 では脚下端 の熱伝達率は無風の場合とあまり変わらないが，他の部 位は増大した。特に脚中央から上と胴体, 腕部では著し

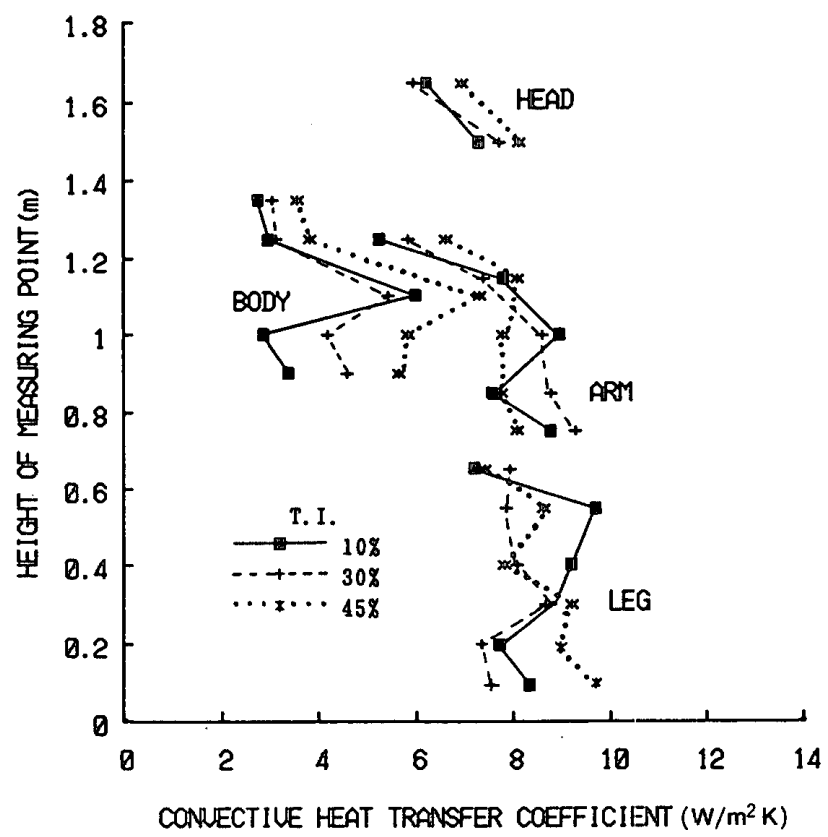

図一4 マネキン各部位別対流熱伝達率（マネキンと周辺との温 度差: $10^{\circ} \mathrm{C}$, 平均気流速度 : $0.2 \mathrm{~m} / \mathrm{s}$ )

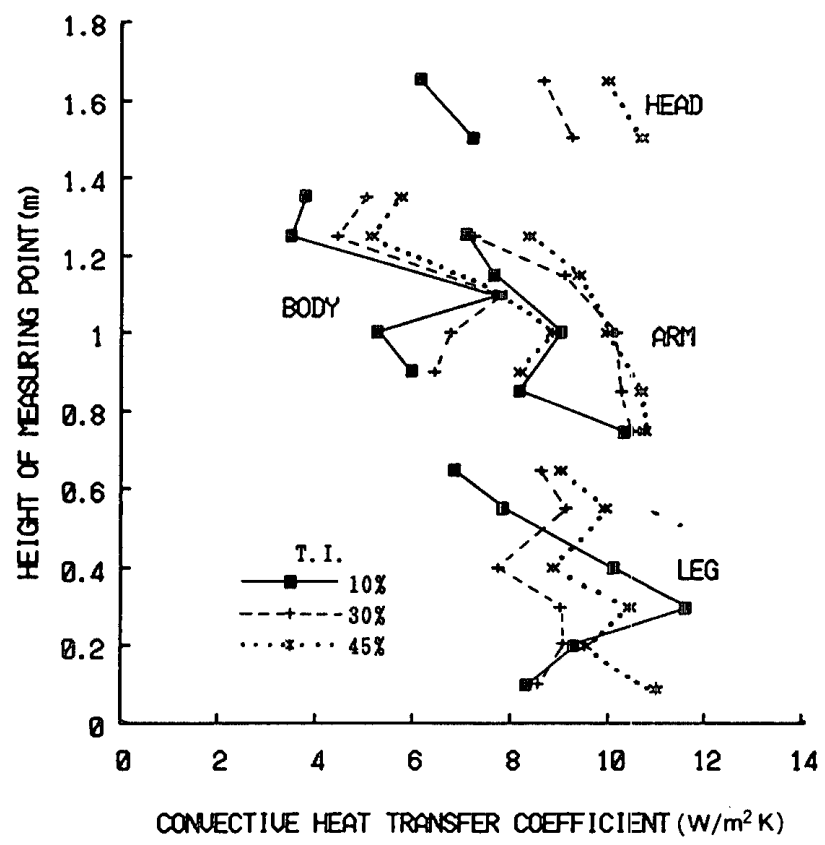

図一5 マネキン各部位別対流熱伝達率（マネキンと周辺との温 度差: $10^{\circ} \mathrm{C}$, 平均気流速度 : $0.3 \mathrm{~m} / \mathrm{s}$ ) 
い増加を示し，対流熱伝達率はほほ脚下端の值に近付い た。胴上端部および頭部ではあまり変化がなかった。乱 れの強さの影響は，脚および腕下端部では規則性が現れ なかったが, 脚, 腕, 胴の上部および頭では乱れの強さ が大きいほど対流熱伝達率が大きくなる傾向が明瞭に なった。平均流速が $0.3 \mathrm{~m} / \mathrm{s}$ の図一 5 では, 脚下端の対 流熱伝達率までもが 1 ～ $2 \mathrm{~W} / \mathrm{m}^{2} \mathrm{~K}$ 上昇し，脚部および 腕の熱伝達率はより增大し上下の差があまりなくなっ た。胴部でも同程度の増加を示し乱れの強さが大きいほ ゼ熱伝達率が大きくなる傾向が明瞭に現れた。特に頭で はこの傾向は著しかった。平均流速が $0.42 \mathrm{~m} / \mathrm{s}$ の図一 6 では脚下端の熱伝達率が $8 \sim 12 \mathrm{~W} / \mathrm{m}^{2} \mathrm{~K}$ まで上昇し, よ り上部でも著しい上昇を示した。また乱れの強さの差に よる熱伝達率の差がより拡大し, 頭部では乱れの強さが $30 \%$ の時, 対流熱伝達率は的 $9 \mathrm{~W} / \mathrm{m}^{2} \mathrm{~K}$ であるが， 45 $\%$ の時は約 $12 \mathrm{~W} / \mathrm{m}^{2} \mathrm{~K}$ でほぼ脚下端と同じ大きさと なった。

脚下端の対流熱伝達率は平均流速 $0.2 \mathrm{~m} / \mathrm{s}$ までは自然 対流時の值とほぼ同じ值にとどまり, 流速 $0.3 \mathrm{~m} / \mathrm{s}$ 以上 でやや増加したが，これはこの流速の境界以下では自然 対流が卓越することを示す。このことは，この流速境界 以下では乱れの強さの影響が不明確であったのに対し， この境界以上では乱れの強さの增大と対流熱伝達率の增 大の関係が明確に現れたことからも言える。胴上部およ び頭部で乱れの強さの影響が強制対流の流速が遅い段階 から明らかになるのは, 上向きの自然対流の水平の強制 対流による偏向が下部で始まり，上部では自然対流が風 下側へ回ってしまうためであろう。

マネキンの表面温度と周辺温度の差が各々 $10^{\circ} \mathrm{C}$,

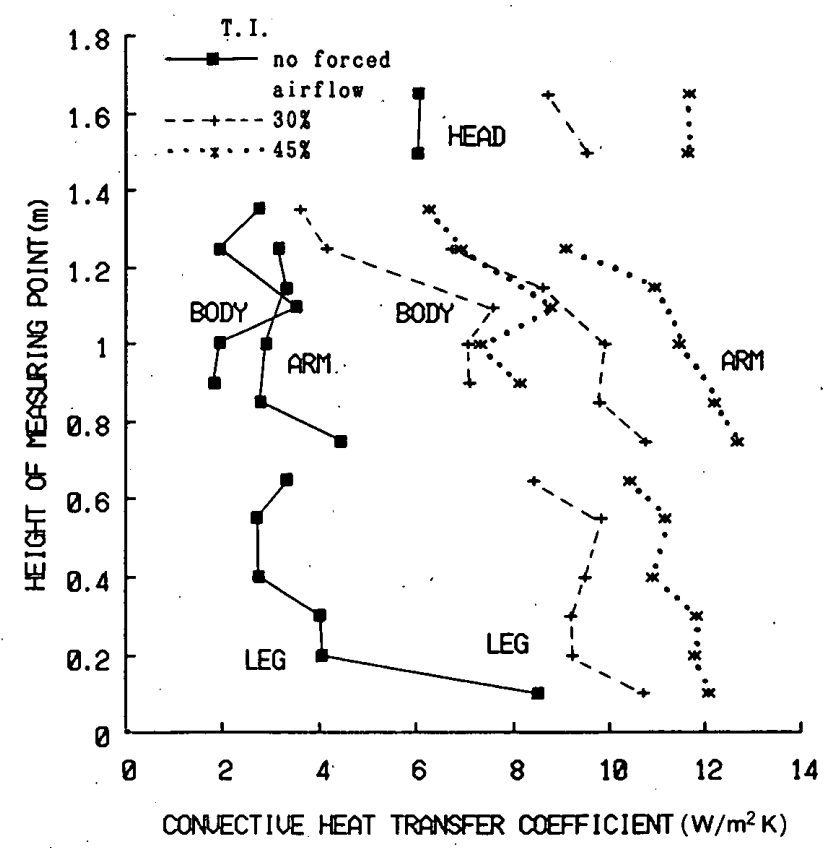

図一6 マネキン各部位別対流熱伝達率（マネキンと周辺との温 度差: $10^{\circ} \mathrm{C}$, 平均気流速度 $: 0.42 \mathrm{~m} / \mathrm{s}$ ) $7^{\circ} \mathrm{C}$ の時の各部位別の対流熱伝達率を各部の表面積で加 重平均して求めたマネキン全身の平均対流熱伝達率を図 一7に示す。マネキンの表面温度と周辺温度の差が $7^{\circ} \mathrm{C}$ の時の, 気流の乱れの強さによるマネキン各部位の対流 熱伝達率は温度差が $10^{\circ} \mathrm{C}$ の時と比べて全体的に若干小 さかったが, 乱れの強さによる変化はだいたい同じで あった。気流の乱れの強さが $45 \%$ の場合， $\Delta T=10^{\circ} \mathrm{C}$ の時の対流熱伝達率は $\Delta T=7^{\circ} \mathrm{C}$ の時より大きいが, そ の差は約 2-3\%であった。乱れの強さが $15 \%$ および $30 \%$ の時は, 流速が $0.3,0.42 \mathrm{~m} / \mathrm{s}$ の場合は $\Delta T=$ $10^{\circ} \mathrm{C}$ の時が若干大きい值を示したが流速 $0.12,0.2$ $\mathrm{m} / \mathrm{s}$ の時はこの傾向は現れなかった。

各々の実験条件下におけるマネキンの各部位ごとの熱 流速の変動度を次のように定義する。

$$
D=\mathrm{S} . \mathrm{D} . / \mathrm{AVE} \text {. }
$$

ここで, $D$ : 各部位ごとの熱流束の変動度

S. D. : 各部位ごとの 100 個の熱流束測定值の標 準偏差. $\left(\mathrm{W} / \mathrm{m}^{2}\right)$

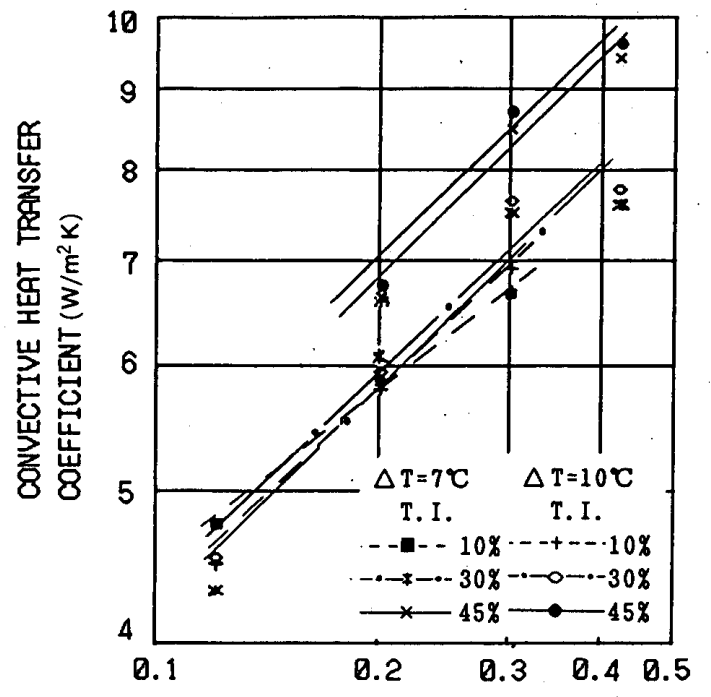

MEAN AIR UELOCITY (m/s)

図一7 $\Delta=7^{\circ} \mathrm{C}$ および $10^{\circ} \mathrm{C}$ の時のマネキン全身加重平均対流 熱伝達率

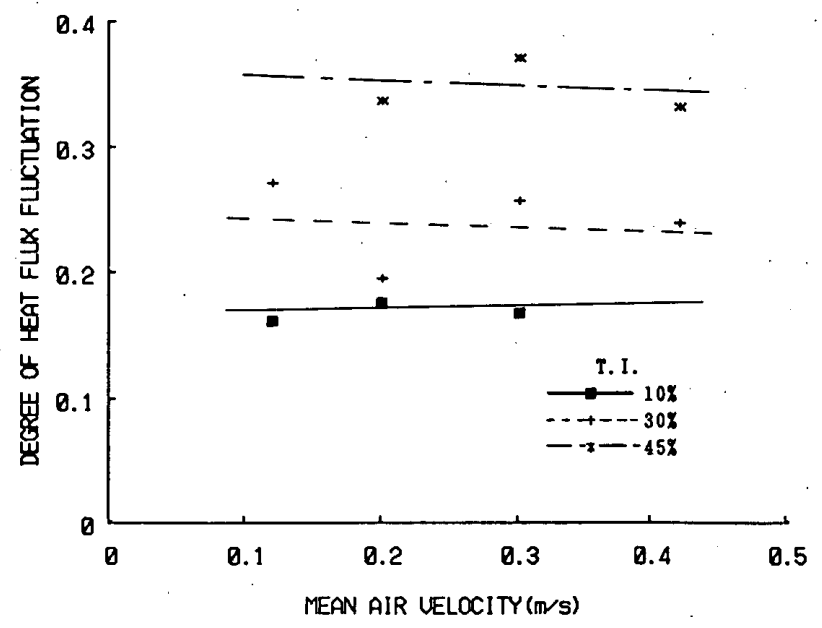

図一8 乱れの強さと熱流束の変動度の関係 
AVE： 100 個の測定熱流束の平均値 $\left(\mathrm{W} / \mathrm{m}^{2}\right)$ 各実験条件について各部位ごとの熱流束変動值をマネキ ンの全身にわたって平均した熱流束変動度を図一8に示 す。図中の各線は乱れの強さ別の回帰直線である。各流 速ごとに若干の差はあるが, 乱れの強さが $45 \%$ の時の 熱流束変動度は約 $0.35,30 \%$ の時は約 $0.24,10 \%$ の 時は約 0.18 であり, 乱れの強さが大きいほど熱流速の 変動度が大きいことが示された。

\section{4. 考 察}

乱れの強さによる対流熱伝達率の変化を示した図一3 ～6より，一般的に乱れの強さが大きいほど対流熱伝達 率が大きいと言える。強制対流の平均流速が $0.3 \mathrm{~m} / \mathrm{s}$ で ある図一5の場合，乱れの強さが $45 \%$ の場合は $10 \%$ の場合に比べて対流熱伝達率が全身で約 1.26 倍, 頭部 では約 1.55 倍大きかった。

Toy らは加熱黄銅垂直円柱に関して強制対流下にお ける対流熱伝達率を測定し，その結果を Frössling の理 論値とSchmidt らの実験式と比較し，Schmidt らの実 験式とはよく一致しているが Frössling の理論值よりは $8 \%$ 程度大きかったと報告し，この原因は理論値では 考慮していない主流の乱れによると思われると言ってい る'1)。

F anger らは普段着で椅座の被験者の後頭部を対象に し，平均流速を $0.05 \mathrm{~m} / \mathrm{s}$ から， $0.4 \mathrm{~m} / \mathrm{s}$ まで変えなが ら行った実験で乱れの強さが大きいほどドラフトによる 不快を感じる被験者の比率が高いと報告した臬。本研究 においては $0.3,0.42 \mathrm{~m} / \mathrm{s}$ の比較的流速が大きい時は乱 れの強さが大きいほど対流熱伝達率が大きかったが気流 が低速の時はさほど差がなかった。このような違いの原 因として，人体の気流・熱流による刺激に対する反応の 生理的な差の他に, Fanger らの実験では椅座であるた め後頭部において自然対流の影響が少なかったのに対 し，本実験の場合は立位マネキンで強制対流が小さい時 は自然対流が相対的に大きく，影響を及ぼしたといった 物理的側面も考えられる。Clark らは0.15 1.4 m/s の 気流に被験者の頭部をさらして頭部の垂直中心線上の 4 か所の対流熱伝達率を測定し, 気流速が大きい時の 4 点 の対流熱伝達率の変化は近似であったが， $0.15 \mathrm{~m} / \mathrm{s} の$ 時は異なる傾向が見られて，これは自然対流が水平の強 制対流より大きいため強制対流が自然対流を完全に代替 することができず，気流が自然，強制の混合状態になる ためと説明している ${ }^{12)}$ 。

乱れの強さが大きいほど人間が不快感を強く感じる理 由として Mayer は乱れの強さが大きくなるに従って人 体の対流熱伝達率が大きくなるためと説明しており ${ }^{9 !}$, Madsen は乱れの強さが大きいほど人体からの熱流束が 大きくなるためと提起している ${ }^{13)}$ 。Fanger らは乱れの
強さが大きくなるに従って人体の皮膚温度の変動が大き くなり，この皮膚温度の変化は寒さに対しての警告信号 として脳に伝わり，この警告信号に対応して人体の調節 を促すものとしてドラフトによる不快を感じると説明し ている ${ }^{8)}$ 。本研究の場合, 強制対流が大きい時は, 乱れ の強さが大きいほど対流熱伝達率が大きくなり, 小さい 時は乱れの強さによる対流熱伝達率の差はあまり大きく なかったが，測定したマネキン各部位の熱流束と表面温 度の変動度は強制対流が大きい時も小さい時も乱れの強 さが大きいほど大きかった。

純自然対流領域における垂直シリンダの平均自然対流 熱伝達率を示す式が次のように与えられる141。

$$
\begin{aligned}
N u_{d}(\text { free }) & =0.522\left(G r_{d}^{\prime}\right)^{1 / 4 \ldots \ldots . .} \\
\text { ここで, } G r_{d}^{\prime} & =\frac{g \beta \Delta t D^{4}}{\nu^{2} L} \\
D & : \text { シリンダの直径 }(\mathrm{m}) \\
L & : \text { シリンダの高さ }(\mathrm{m})
\end{aligned}
$$

また，強制対流における垂直シリンダの強制対流熱伝達 率を表すのがヒルパートの式として次のように示され る $^{15)}$ 。

$$
\begin{aligned}
& N u_{d}(\text { forced })=0.615 R e_{d}^{0.466} \ldots \ldots \ldots \\
& \text { ここで, } R e_{d}=\frac{u D}{\nu} \\
& u: \text { 強制対流の流速 }(\mathrm{m} / \mathrm{s})
\end{aligned}
$$

マネキンの腕を直径 $0.1 \mathrm{~m}$, 長さ $0.7 \mathrm{~m}$, 温度差 $10^{\circ} \mathrm{C}$ の加熱円柱と仮定して, 無風の時と平均流速 $0.12 \mathrm{~m} / \mathrm{s}$ の時の $N u$ 数を上式（3），(4) で計算してみると各々 10.9，13.4になる。混合対流熱伝達率についての自然 対流と強制対流の相互作用は実験的に $2 つ の$ 対流のべク トル和として知られている。したがって,$N u$ (mixed) $=\left(10.9^{2}+13.4^{2}\right)^{1 / 2}=17.3$ になる。本実験結果の腕部に おける $N u$ 数は図一6 の無風時が約 12.4 , 図一4の平均 流速 $0.12 \mathrm{~m} / \mathrm{s}$, 乱れの強さが $30 \%$ の強制対流が存在す る時は 21.4 になる。本実験の值がやや高いのは腕部が 正確な円柱形でないこと，腕部と胴部との気流が千渉す ることと本実験における気流の乱れなどが原因として考 えられる。

図一7に示されているマネキン全身の平均対流熱伝達 率と他の文献1), 15) 17) の対流熱伝達率とを比べてみると 本実験の場合がいくぶん大きい。これは，本研究ではマ ネキンの強制対流に正対する部分だけを考虑に入れてい るのに対して他の研究では直接さらされない後方等も考 慮に入れているためと思われる。

ASHRAE，ISO 等では室内温熱環境の快適条件に気 流速度の範囲も定めているが, 実際この範卧内の平均流 速にさらされた室内居住者がドラフトによる不快感を持 つという研究結果も出ており", これは気流の乱れの強 さが一つの原因として考えられる。室内快邂基準に気流 の平均流速だけでなく乱れの強さも含まれる必要がある 
と思われる。

\section{5. まとめ}

強制対流の乱れの強さによるサーマルマネキンの各部 位の対流熱伝達率の変化を調べた結果; 乱れの強さが大 きいほど対流熱伝達率が大きいことと, マネキンの熱流 束と表面温度の変動度が大きいことがわかった。このこ とは室内気流の平均流速が快適基準速度の範囲内にあっ ても乱れの強さが大きい場合は室内居住者がドラフトに よる不快を感じることがありうることを意味する。室内 温熱環境を構成する因子の一つである気流の扱いはその 平均流速だけでなく乱れの強さも同時に行う必要がある と考えられる。また, 強制対流が $0.2 \mathrm{~m} / \mathrm{s}$ 以下の低流速 の時はマネキン各部位の対流熱伝達率は自然対流の上昇 気流と強制対流の混合気流に影響され，各部位ごとの対 流熱伝達率の分布の形はより速い強制対流がある時とは 異なることが示された。今後，快適条件に対する気流の 物理的性状に関しても，人体の側面，後面や着衣また椅 座のモデルを用いてより幅広い実験を続ける必要がある と思われる。

\section{参考文献}

1) Colin, J. et al. : Experimental determination of coefficient of heat exchanges by convection of human body, J. Appl. Physiol. 22( 1 ), pp. 31 38, 1967

2) Houghten, F.C. et al. : Draft temperatures and velocities in relation to skin temperature and feeling of warmth, ASHVE Trans., 44, pp. 289 308, 1938

3) McIntyre, D. A. : The effect of air movement on thermal comfort and sensation, Indoor Climate, Danish Building Research. Institute, Copenhagen, pp.541 560, 1979

4) Berglund, L.G. et al.' : Subjective human response to low-level air current and asymmetric radiation, ASHRAE Trans., 93( 1 ), pp. 497 523, 1987

5) Hanzawa, H. et al. : Airflow charactristics in the occupied zone of ventilated spaces, ASHRAE Trans., 93 (1) , pp. 524 538, 1987
6) Fanger, P. O. et al. : Discomfort due to air velocities in spaces, Proc. of Meeting of commission B1, B2, E1 of Int. Instit. Refrig., 4, pp. 289 296, 1977

7) Melikov, A.K. : Quantifying draught risk, Technical review, No2, Brüel \& Kjaer, 1988

8) Fanger, P. O. et al. : Air turbulence and sensation of draught, Energy and Buildings, 12, pp. 21 39, 1988

9) Mayer, E. : Influence of turbulence on the convective surface heat transfer coefficient, Proc. Third International conference on Indoor Air Quality and climate, Stokholm, Vol.5, Swedish Council for Building Research, pp. $377 \sim 382,1984$

10）李 徹球ほか：加熱円柱組合せ人体モデルによる人体周 辺の自然対流の性状と人体の部位別自然対流熱伝達率に 関する実測結果, 日本建築学会計画系論文報告集, 第 416 号, pp. 25 34, 1990. 10

11) Toy, N. et al. : A surface plate calorimeter, Jnl Physics E. scient. Instrum. 6, pp. 702 704, 1973

12) Clark, R.P. et al. : Forced convection around the human head, J. physiol. 244, pp. 295 302, 1975

13) Madsen, E. : Why low air velocities may cause thermal discomfort, Proc. Third International conference on Indoor Air Quality and climate, Stokholm, Vol. 5, Swedish Council for Building Research, pp. 377 382, 1984

14) Gebhart, B. : Heat transfer, McGraw-Hill, 1961

15) Rapp, G. M. : Convective heat transfer and convective coefficients of nude man, cylinder and spheres at low air velocities, ASHRAE Trans., pp. 75 87, 1973

16) Nishi, Y. et al. : Direct evaluation of convective heat transfer coefficient by naphthalene sublimation, J. Appl. Physiol., 29( 6 ), pp. 830 838, 1970

17) Tamari, Y. et al. : Convective heat transfer from the human form, J. Appl. Physiol., 32( 2 ), pp. 227 233, 1972

18）李 徹球ほか：乱流を制御した微風速発生装置について （室内気流中の乱れの強さによるサーマルマネキン各部 位の対流熱伝達率の変化に関する研究 その1), 日本建 築学会東海支部研究報告集, pp. 273 276, 1991.2

(1991 年 5 月 10 日原稿受理, 1991 年 9 月 4 日採用決定) 